UDC 621. 316.93

$621.3 .015 .33: 621.3,064$

\title{
開閉インパルスによる雷しゃへい実験と その考察
}

電力中央砢智所

電力中块研究所

\section{1. まえがき}

送電線耐雷設計のうちの架空地線の雷しゃへいに関 しては，各種の洘え方，モデルを使った宾験検討なよ゙ 数多く発表されている(1) (8)。最近の代表的な考え方 としては, Armstrong-Whitehead 両氏の説(7)，モデ

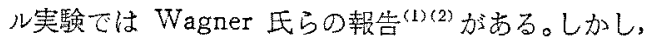
現状ではこれらの結果で十分満足されているとは判断 できない。これは自然雷の不明確さ，実線路の実績は あくのむつかしさなどが原因である。特にモデル実験 では自然雷との対比も含めて雷慗模擬のサージ電圧波 形や極性の妥当性，モデルの縮尺に含まれない放電現 象の非直線性の扱い方などが問題になり，絶対論を論 じることはできない。しかしながら，雷しゃへいのよ うな問題は, 理論, 実験結果と実績の 3 つ它合致させ ることが一つの手法であると质えるととができる。こ の考え方に立って，将枽への1ステップとして可能な 笵图の大形モデルで実験的に検討した香のである。実 験は雷しゃへい特性に影響すると予想される要因につ いて検討し，その結果とこれらの結果から雷しゃへい について若干の検討を芳えて示した。なお，ての実験 で结開閉インパルスを使ったが，てれは電極先端の電 荷生成速度を雷インパルスよりも遲くするためで， Wagner 氏らも䉓荷生成速度は雷インパルスよりも䐅 くするほうが自然雷に近つくとしてしている(1)。

\section{2. 実験の概要}

\section{$\langle 2 \cdot 1\rangle$ 実験の前提 実験の前提条件は，発表さ}

Experimental Study of Lightning Shield Using Switching Impluse and Considerration of Results. By I. KISHIZIMA, Member \& K. INOUE, Member '(Central Research Institute of Electric Power Industry)

岸䖶 丽: 正員, 電力中央研焢所

并上數之: 正具。電力中央研究所
岸 嶋 勇
井上 呚 之

井上敦之

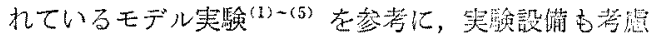
して次のように決めた。

雷揧模擬の電極は先端を半惩で丸るくした $12 \mathrm{mm \phi}$

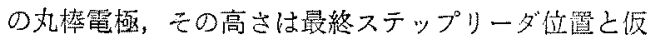
定し，雷電正は開閶インパルスで模擬する。極性は自 然雷比多い負極性とする。モデルの大きさは $0.5 \times 2$ $\mathrm{m}$ ，電極の高さは $2 \mathrm{~m}$ 灾でしする。大厸面は金属板で

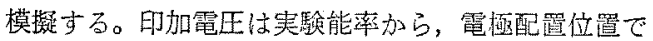
70〜80\% のフラッシオーバ電王とする。

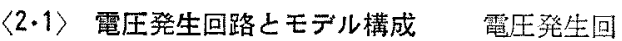
路は. 第1四に示す通りで，発生する波形は約 150

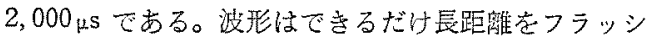
オーバさせるため，実験刘象範明のギャップ長で低い フラッシオーバ特性を示す $150 \times 2,000 \mu \mathrm{s}$ とした。

基本モデルは，平地では第 2 図，傾斜徘では第3図 のように若えた。電極は全て重直配置とした。架空地 線，相導体は $1.6 \mathrm{~mm} \phi$ の銅線を使い，接地老原則之 した。

第2図，第3因に示した記号は，組合せて使用寸る

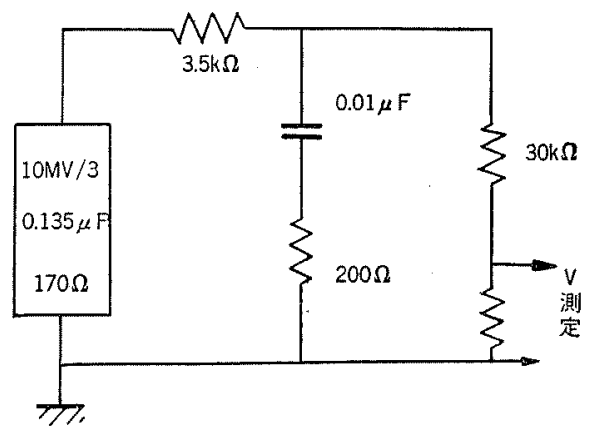

第 1 図 開閉インパルス発生回路

Fig. 1. Generating circuit of switching impuls. 


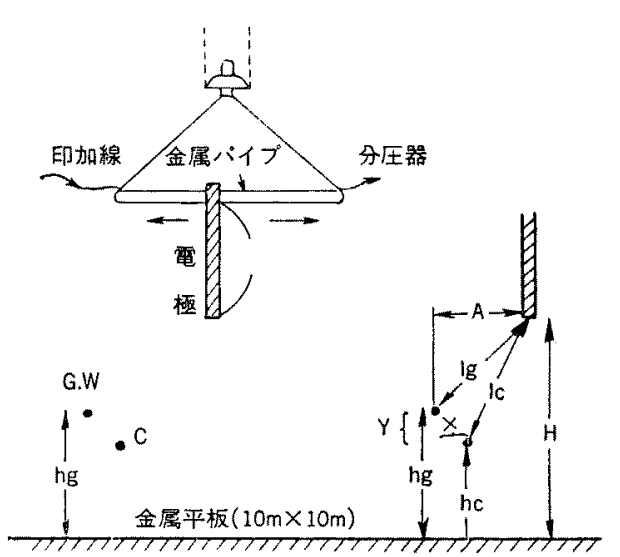

籍 2 図送觉線モデルの構成(平地)

Fig. 2. Organization of transmission lines model. (Flat area)

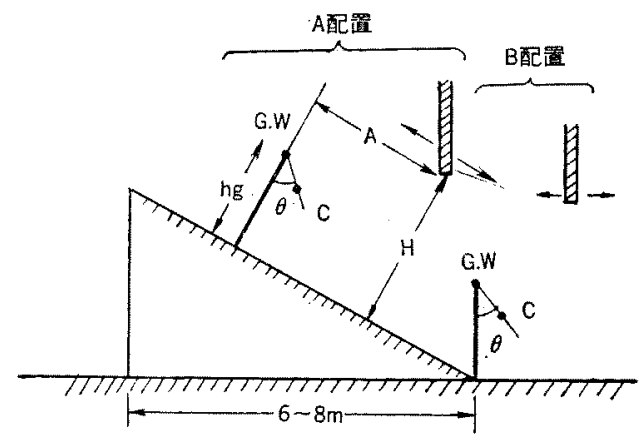

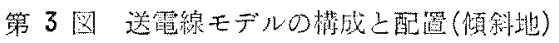

Fig. 3. Organization and arrangement of transmission lines model (Slope area).

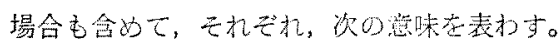

$H:$ 電極の高さ

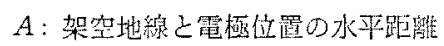

hg: 架空地線の高さ

$h c:$ 相導体の高さ

$l g:$ 電極先端加ら架空地泉までの距離

$l c:$ 電極先端加ら相嶈体までの距嚾

$X:$ 架空地線上相導体の水平距䧹

$Y:$ 架空地線之相導体の高さの差

$\theta:$ し々 い角

\section{〈2.3〉実験方法と結果の取扱い}

実験は各配置 で $H$ を固定し，A を $10 \sim 20 \mathrm{~cm}$ ステップで移動し 各場所人の故電率を求め，第 4 四の上うな分有曲線支 求めた。放電場所の確認は目視と写貫によった。 1 電 極位置の電压印加は放電汃 50 回に達するまでとし， 相導体が多いときはこの2 倍とした。しゃへい率は期 4 图のような分布曲線加ら面樍計算で求めた。また，

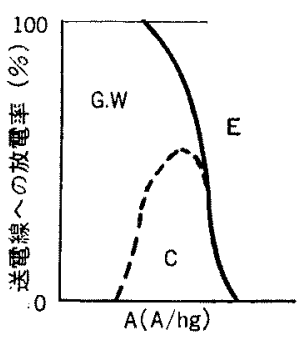

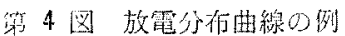

Fig. 4. Example of distribution curve by this method.

送電線への放電摔 $P$ に刘応する $A$ または $A / h_{g}$ を

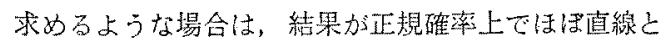
して报うことができるのでこの苗線から求めた。

$\langle 2.4\rangle$ 実験項目矢駰項目は，（1）大地之喿空 地線の組合甘，(2)大地，架空地線の他に相㑭体党追 加した塄合，の二つに大別寸るこ上ができる。前者を

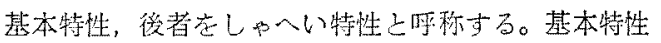

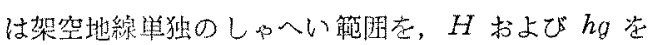
替えてその変化索調へた。しゃへい特性は主にしゃへ い率に影䋏が予想される相導体の高さと，配置数の影

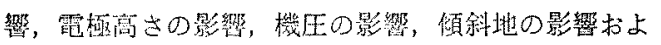
び，相摹体下部のしゃへい線の效果などについて検討 した。これらの零龭の $H, \theta, h g$ 执よびhcは，その

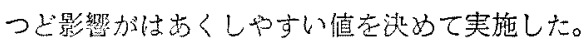

\section{3. 実験結果}

〈3.1〉基本特性 第 1 表は架空地線のしゅへい 範国走示す分布曲線加方，架空地線への放電率 $P_{\theta}=$ 95,50 およじ $5 \%$ 亿対心する $\mathrm{A} / \mathrm{hg}$ と， $\sigma$ を求めて

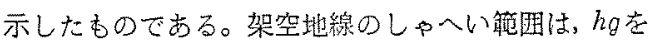
一定上し，H䯩汃す机ば広くなる。 $H$ 学固定し て坷を低くくしても同㥞である。しかし，いずれる

第 1 表 基本特性の数值表示

Table 1. Number indicate of basic characteristic.

\begin{tabular}{|c|c|c|c|c|c|c|}
\hline \multirow{2}{*}{ 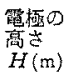 } & \multirow{2}{*}{$\begin{array}{l}\text { モデル } \\
\text { の苟点 } \\
h g(\mathrm{~m})\end{array}$} & \multirow{2}{*}{$H / h g$} & \multicolumn{3}{|c|}{$P_{G}(\%)$ を艺える $A / h g$} & \multirow{2}{*}{$\left(\begin{array}{c}\sigma \\
\text { カッ内は } \\
\sigma / 50(\%)\end{array}\right)$} \\
\hline & & & $95(\%)$ & $50(\%)$ & $5(\%)$ & \\
\hline 1.0 & 0,5 & 2 & 2.00 & 2.40 & 2.75 & $0.23(10.3)$ \\
\hline$"$ & 1.0 & 1 & 1.10 & 1.31 & 1.53 & $0.14(9.4)$ \\
\hline 1.5 & 0.5 & 3 & 2. 37 & 2.97 & 3.60 & $0.38(12.8)$ \\
\hline$"$ & 1. & 1.5 & & & & $0.23(12.2)$ \\
\hline$"$ & 1.5 & 1 & 1. 18 & 1.30 & 1.45 & $0.12(9.2)$ \\
\hline 2.0 & 0.5 & 4 & 2.55 & 3.50 & 4.43 & $0.45(13.0)$ \\
\hline$"$ & 1.0 & 2 & & 2.23 & 2.70 & $0.27(12.1)$ \\
\hline$"$ & 1.5 & 1.33 & 1.32 & 1.60 & 1.88 & $0.17(10.6)$ \\
\hline " & 2.0 & 1 & 1.04 & 1.26 & 1.48 & $0.14(11.1)$ \\
\hline
\end{tabular}




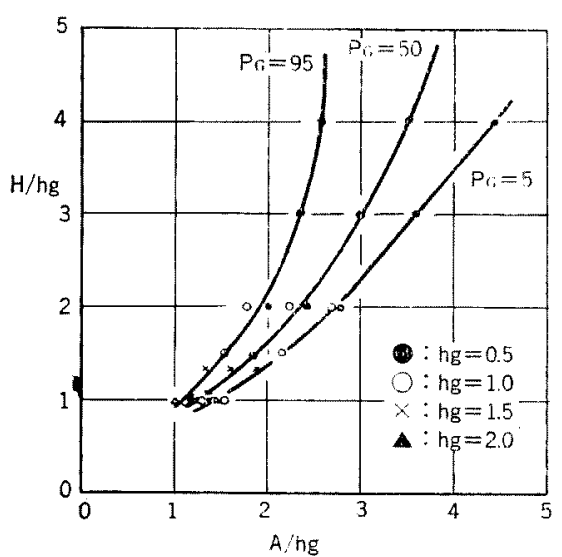

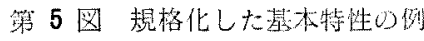

Fig. 5. Example of standardized basic characteristic.

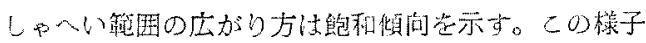

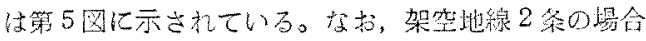

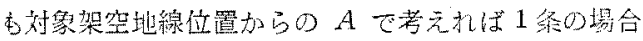

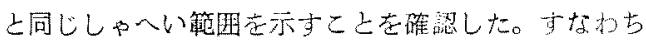

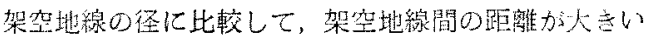
$(h g=0.5 \mathrm{~m}$ に対して, 架空地線間留は $15 \mathrm{~cm})$, ため

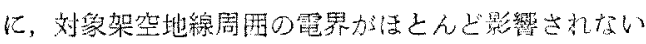
ためと考元る。

〈3.2〉しゃへい率に影響する要因の倹討 各㮔

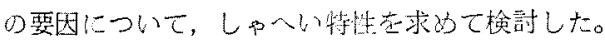

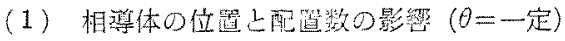

相導体の位置は，古る日に対して任意の高さが考え られ，この高さ $6 c / h g$ 加变化したときのしゃへい率の

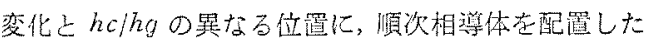

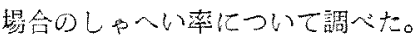

第6図は，hc/hg 在变詣出たときの結果で，しゃ へい率は hc/hg が小さいによ゙良くなることがわかる。 $h c / h g=0.9 \sim 0.5$ は, 実送雪線の視尊体の高さを参考 に決めたもので，この範罒のしゃへい率の变化は， $\theta=45^{\circ}$ 乙 $37.5^{\circ}$ では約 $10 \%, 0=30^{\circ}$ では約 $8 \%$ で略

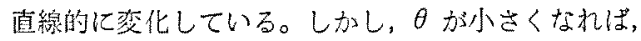

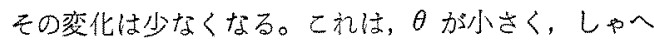
い条件が良いために变化は少ない上法えられる。ここ では，hc/hg が小さい活ど，しゃ八い率が良くなるこ とが焉要な結果である。

相揅体を順次追加配置した塄合の結果は籍 2 表に示 した。総合しゃへい率は坐相等体在対象にしたむので 2 相への放電は 1 回のしゃ人い失稘, 各相のしゃへい 率では，2相にわたる放電は各相をれぞれに1回のし やい失敗しして扱った。

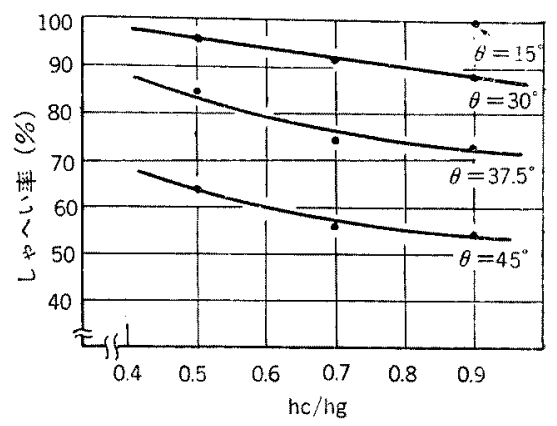

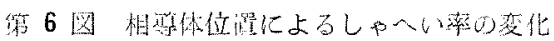

Fig. 6. Variation of shielding ratio by location of conductors.

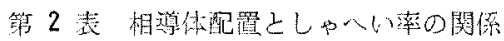

Table 2. Relation of conductors arrengement and shielding ratio.

\begin{tabular}{|c|c|c|c|c|c|c|c|c|c|c|}
\hline \multirow{2}{*}{\multicolumn{2}{|c|}{ 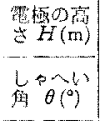 }} & \multicolumn{3}{|c|}{$H=1.5(\mathrm{~m})$} & \multicolumn{6}{|c|}{$H=1.0(\mathrm{~m})$} \\
\hline & & \multicolumn{3}{|c|}{$0=45^{\circ}$} & \multicolumn{3}{|c|}{$\theta=45^{\circ}$} & \multicolumn{3}{|c|}{$\theta=30^{\circ}$} \\
\hline L & 総合 & $\begin{array}{l}(4) \\
75.5\end{array}$ & $\begin{array}{l}(\%) \\
81 .\end{array}$ & $\begin{array}{l}(\%) \\
82.5\end{array}$ & $\begin{array}{r}(\%) \\
52.8\end{array}$ & $\begin{array}{l}\%) \\
47 \% 0\end{array}$ & $\begin{array}{r}(\%) \\
48.9\end{array}$ & $\begin{array}{r}(\%) \\
88.0\end{array}$ & $\begin{array}{c}(\%) \\
90.4\end{array}$ & $\begin{array}{l}(\%) \\
91.6)\end{array}$ \\
\hline$n$ & 上相 & 75.5 & 86.3 & 84.3 & 52.8 & 87.4 & 86.2 & 88.0 & 94.6 & 93.3 \\
\hline 哆 & 中相 & - & 94.0 & 92.8 & - & 59.8 & 78.8 & - & 95.8 & 96.5 \\
\hline$(\%)$ & 下相 & - & - & 97.0 & - & - & 77.9 & - & - & 100 \\
\hline
\end{tabular}

総合しゃへい率は各ケースと屯相導体の配置数で变

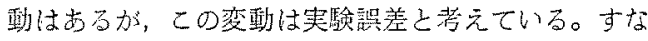
わ5，同一条件の繰返し奏験でも，しゃ八い率の算出

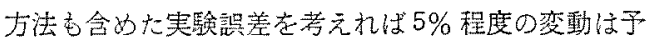
想されるし，実际に経験している。したかっって，第 2 表の筑合しゃへい率它相導体の配置数に関係なく，浔 浔日だけで決まると判断でる。各相のしゃへい率に 注目すると，上相では，上相だけのときのより中相ま で莭䈯した上きの方が良く，下相の配置によっては， あまり変化がない。一力，中相では，下相の状態で異 なり，下相にしゃへい失敗が多いときは良くなり，し 中八い失敗が少ないटきは变化加少ない。この結果は 相導体を追加配幒すると新たに配置した相等体への放 電は，㪛置の最も近い相導体加ら移行するといえ る。したがって，総合のしゃへい率には变化が現らか れないといえる。

以上の結果から，上相の $\theta$ 紧是大きい場合は，上 相にしゃへい知がないよう教えれば良いことにな る。いい撸え扎ば，しゃへい率の梌討に相に相当 する相獎体 1 条で十分であるといえる。

(2) 電極高さ $(H)$ の影響 符 7 圈は, $h c / h g$ $=0.7$ の場合について，H别に $\theta$ を变えて求わたし やへい率落したものである。しゃへい率か $80 \%$ 以 


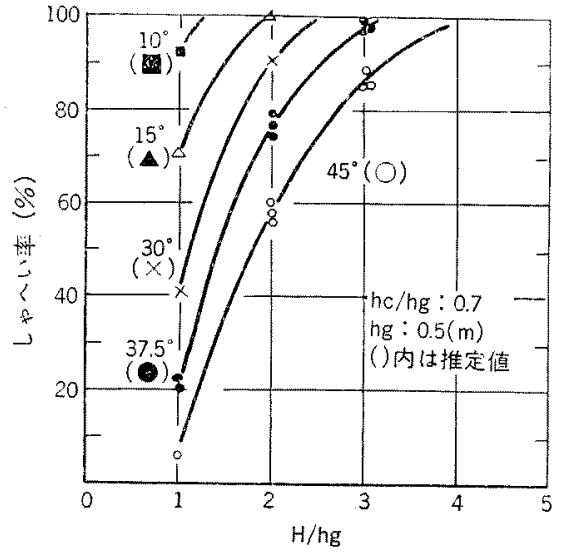

第7 图 電極高さによるしゃへい率の变化 Fig. 7. Variation of shielding ratio by electrode hight.

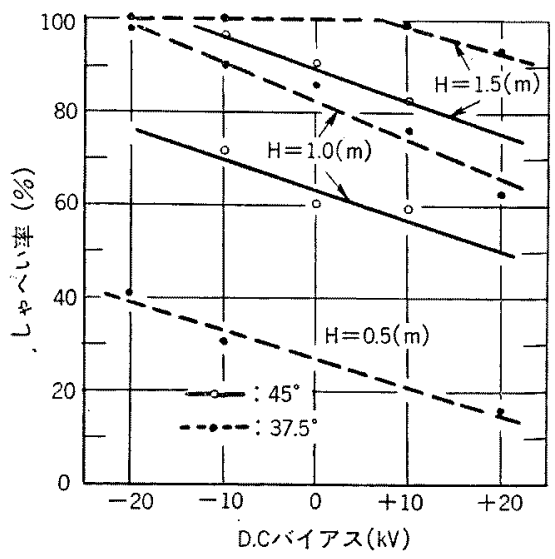

第 8 图 DCバイアスによるしゃへい率の获化

Fig. 8. Variation of shielding ratio by DC bias.

下の場合は，Hが大きくなるに徉ってはぼ直鼣的に

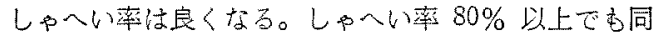

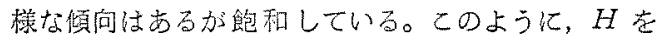
高くするに徒ってしゃへい率が良くなるのて，霓整の 最終ステップリーダの高さを造電線の简さに刘して，

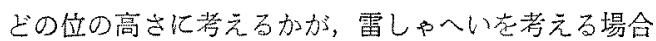
の電要なポイントになる。

（3）機圧の影響 相薘体の機王模擬のバイアス 電压は，表面電位傾度が実遥電線と一敢する上うに決 わた。実送電線の電位傾度は $14 \sim 16 \mathrm{kV} / \mathrm{cm}$ で，てれ

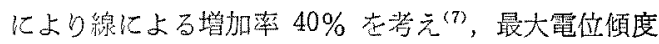
を $20 \mathrm{kV} / \mathrm{cm}$ と仮定した。これは考慮したモデルに対 しては約 $10 \mathrm{kV}$ に相当する( $\theta$ にって若干異なる)。 したかって，直流は $10 \mathrm{kV}$ ，交流梳波高值 $10 \mathrm{kV}$ 老

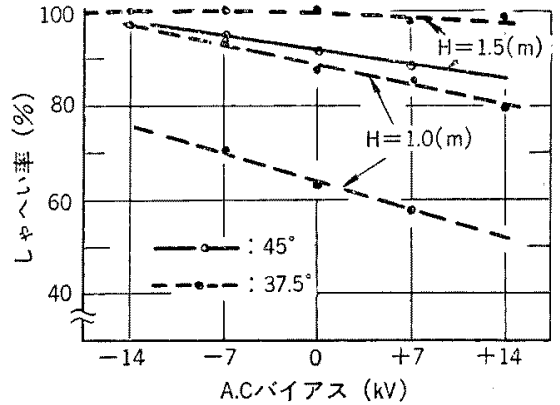

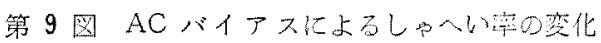

Fig. 9. Variation of shielding ratio by AC bias.

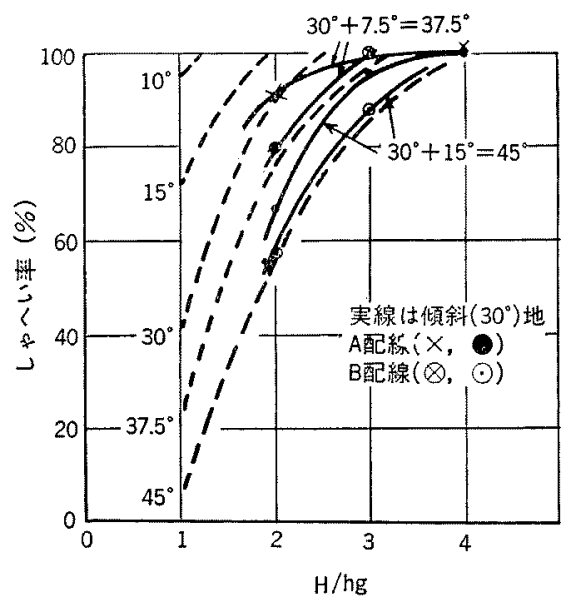

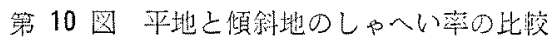
Fig. 10. Comparison of shielding ratio on flat area and slope area.

基準しし，一部 $20 \mathrm{kV}$ まで考えた。

結果は，直流の㘯合を第 8 図に，交流の場合第 9 図に示した。しゃへい率は雷撃の極性安負極性とした

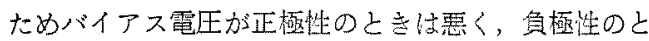
き比くなっている。

$H=1.5 \mathrm{~m}, \theta=37.5^{\circ}$ のケースは，しゃへい率が 100 \%に近いために他のケースと㑯向が珙なるが，他は $H$ および $\theta$ に関係なくバイアス雪圧の影然はほ中一 定である。バイアス電压 $10 \mathrm{kV}$ あたりのしょへい率 の変化は，直流で7〜8\%，交流では 4〜6\% と交流の

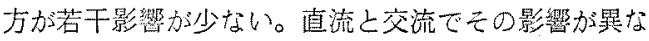
るのは，交流では正負に電王が変化することによる空 間電荷の影繁によるものと考えられる。

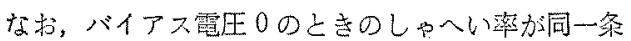
件の第 7 图之珙なるのは，バイアス電源保護の抿抗李 含めた霓源インピーダンスで相薄体が接地された形に 
なり，相導体へ放電しにくくなるためである。

(4) 傾斜地の影響 モデル眍䍛は, 第 3 图に示 した $A ， B$ 配置を対象に傾斜地の角度は $30^{\circ}$ とた。 結果は第 10 图に平地の結果と比茭して示した。実 際のしょい角は $\left(\theta-30^{\circ}\right)$ ○ $15^{\circ}$, 之 $7.5^{\circ}$ になる。し 加し，第 10 因加ら，傾斜角も含めた $\theta=45^{\circ}$ 己 $37.5^{\circ}$ としてしゃへい率見れば， $\left(\theta-30^{\circ}\right)$ の場合よりす平 地の天机近い。すな小ち，㑯斜角念含めた $\theta$ で考元 れば $H / h g=3$ 以下で, $10 \sim 15 \%$ 平地の結果よりし やへい率加良くなっているだけで， $\left(\theta-30^{\circ}\right)$ で考えだ

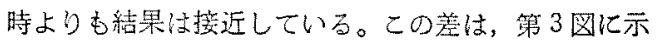
したように電極垂淔に考えたため，一部，放電の出

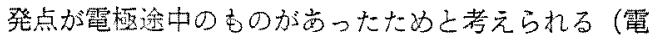
極先端から $10 \mathrm{~cm}$ 位のものはデータに採用した)。一

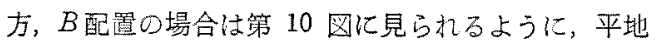
の結果とよく一致している。

(5) 相毞体下部心Lへい線の勃果 UHV 級

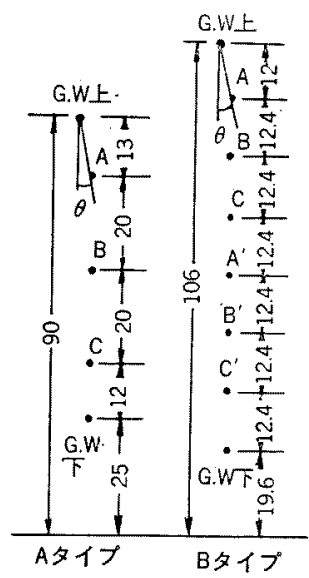

筝 11 図 UHV 級送電楾のモデル

Fig. 11. Model of U.H. V. class transmission lines.

第 3 表 $G . W_{下}$ によるしゃい率の変化(平地)

Table. 3. Variation of shielding ratio by down ground-wire. (Flat Area).

\begin{tabular}{|c|c|c|c|c|c|}
\hline \multirow{2}{*}{ 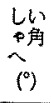 } & \multirow{2}{*}{ 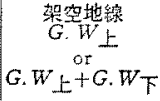 } & \multicolumn{2}{|c|}{ 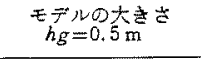 } & \multicolumn{2}{|c|}{$\begin{array}{c}\text { モデルの大きさ } \\
h g=1.0 \mathrm{~m}\end{array}$} \\
\hline & & $H / h g=1$ & $H / h g=2$ & $H / h g=1$ & $H / h g=2$ \\
\hline $0^{\circ}$ & $\begin{array}{c}G . W_{上} \\
G . W_{上}+G \cdot W_{下}\end{array}$ & $\begin{array}{c}100^{(\%)} \\
-\end{array}$ & $\begin{array}{c}100^{(\%)} \\
-\end{array}$ & $\begin{array}{l}(\%) \\
99.8^{*} \\
99.6^{*}\end{array}$ & U \\
\hline $5^{\circ}$ & $\begin{array}{c}G \cdot W_{\text {上 }} \\
G \cdot W_{\text {上 }}+G \cdot W_{\text {T }}\end{array}$ & $\begin{array}{l}98.6^{*} \\
99.8^{*}\end{array}$ & - & $\begin{array}{l}98.4^{*} \\
97.6^{*}\end{array}$ & - \\
\hline $30^{\circ}$ & $\begin{array}{c}G \cdot W_{上} \\
G \cdot W_{上}+G \cdot W_{下}\end{array}$ & - & $\begin{array}{l}97.0^{*} \\
96.1^{*}\end{array}$ & - & - \\
\hline
\end{tabular}

*: 相朗体八の放電は全て上相

昭 $50-9$
の送笔筤では誘等对策の面加ら相導体の下部にしゃ人

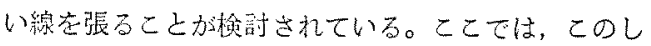
やへい線の雷しゃへい刻果について検討した。おお，

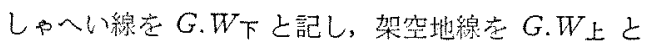
媌す。

対象モデルは第 11 図のように相導体を 3 相分と相

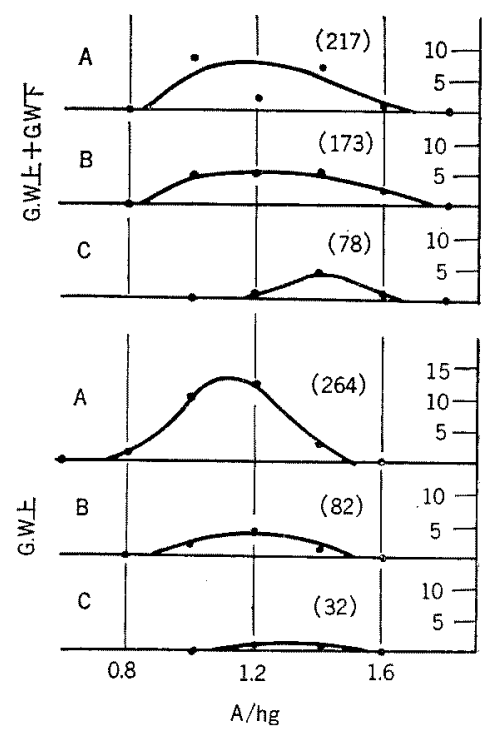

(a) $H=1.0 \mathrm{~m}, H / h g=1, \theta=0$
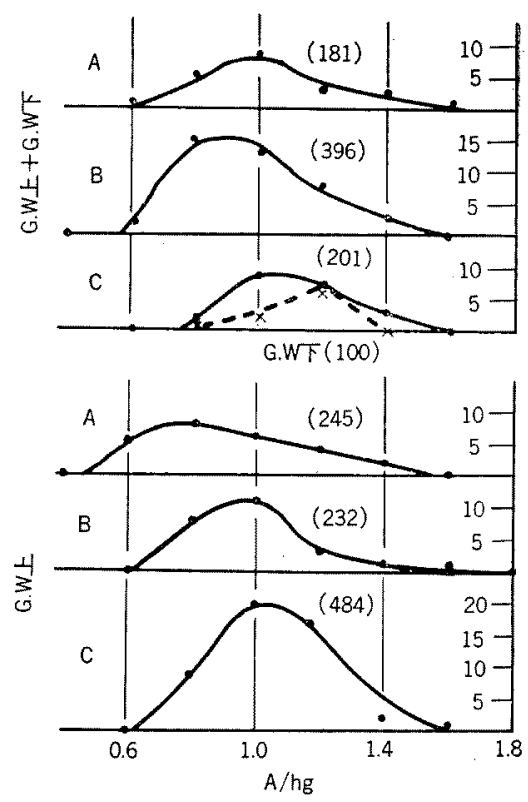

(b) $H=1.5 \mathrm{~m}, H / h g=1.5, \theta=1$

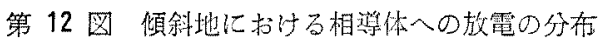

Fig. 12. Distribution of discharge for conductors on slope area. 
第 4 表 G.W下によるしゃへい率の变化 (傾斜地)

Table. 4. Variation of shielding ratio by down ground-wire (Slop Area.).

\begin{tabular}{|c|c|c|c|c|}
\hline \multirow{2}{*}{ Len } & \multirow[b]{2}{*}{ 架架地舀 } & \multirow[b]{2}{*}{$H / h g=\mathfrak{l}$} & \multicolumn{2}{|c|}{$h q=1.0 \mathrm{~m}$} \\
\hline & & & $H / h g=1.5$ & $H / h g=2$ \\
\hline \multirow{2}{*}{$0^{\circ}$} & $G . W_{\text {上 }}$ & $36.6 \%$ & $96.6)$ & $\left.99.7^{*}\right)$ \\
\hline & G. $W_{\text {上 }}+\vec{G} \cdot W_{下}$ & 89.5 & 96.4 & 100 \\
\hline
\end{tabular}

*: 上相，中相八名 1 回故笵

6分の配置䘮考え，それぞれ，AタイプとBタイプ （傾斜地のみ）上した。モデルの高さは，1m を原則 とし，相奬体の両端は $500 \Omega$ で接地した。

平地の場合: 結果は，G.W下のある場合とない場 合を比校して第 3 表に示した。この結果汃らはしゃへ い率は G.W下に影狐されていない。すなわち， $G . W$ 上に放電しない分は全てしゃへい失敗となって 上相に放電している。

〈3.2〉節（1）の結果によ机ば，下部に配置される尊

第 5 表 相算体への放電分布（综涂地） $\left(H=1.5, h g=1.0, Q=0^{\circ}\right)$

Table. 5. Distribution of discharge for conductors (slope area).

\begin{tabular}{|c|c|c|c|c|c|c|c|c|c|}
\hline G. Wo荣化 & 留体 & $\begin{array}{l}0^{(\mathrm{m})} \\
0.8\end{array}$ & 1.0 & 1.2 & 1.4 & 1.6 & 1.8 & 2.0 & 2.2 \\
\hline \multirow{3}{*}{$\begin{array}{c}(ケ-\pi 1) \\
G . W_{\text {上 }} \\
\eta=94 \%\end{array}$} & $\begin{array}{l}A \\
B \\
C \\
A^{\prime}\end{array}$ & 1 & $\begin{array}{l}4 \\
5 \\
2 \\
1\end{array}$ & \begin{tabular}{l|}
2 \\
5 \\
4
\end{tabular} & $\begin{array}{l}2 \\
6 \\
6 \\
2\end{array}$ & \begin{tabular}{l|}
6 \\
5 \\
6
\end{tabular} & $\begin{array}{l}2 \\
1 \\
1\end{array}$ & $\begin{array}{l}1 \\
1\end{array}$ & \\
\hline & $\begin{array}{l}A B \\
B C \\
C A^{\prime} \\
B A^{\prime}\end{array}$ & & $\begin{array}{l}1 \\
1\end{array}$ & 1 & $\begin{array}{l}3 \\
1 \\
1\end{array}$ & $\begin{array}{l}3 \\
2\end{array}$ & & & \\
\hline & 謰 & 1 & 10 & 10 & 11 & 12 & 4 & 2 & 0 \\
\hline \multirow{3}{*}{$\begin{array}{c}(ケ-\pi 2) \\
G . W_{上} \\
+ \\
G . W_{F} \\
\eta=97 \%\end{array}$} & $\begin{array}{l}A \\
B \\
C \\
A^{\prime}\end{array}$ & & $\begin{array}{l}1 \\
5 \\
1\end{array}$ & $\begin{array}{l}1 \\
3 \\
1\end{array}$ & $\begin{array}{l}2 \\
2 \\
1\end{array}$ & $\begin{array}{l}3 \\
1\end{array}$ & $\begin{array}{l}1 \\
3 \\
1\end{array}$ & & \\
\hline & $\begin{array}{l}A B \\
B C\end{array}$ & & & 1 & & & $\begin{array}{l}1 \\
1\end{array}$ & & \\
\hline & ât & 0 & 7 & 4 & 5 & 4 & 3 & 0 & 0 \\
\hline \multirow{4}{*}{$\begin{array}{c}(ケ ー ス 3) \\
G . W_{上} \\
+ \\
G . W_{下} \\
(3 \mathrm{~m} \text { 張出 }) \\
\eta=95 \%\end{array}$} & $\begin{array}{l}A \\
B \\
C \\
A^{\prime} \\
B^{\prime}\end{array}$ & 1 & $\begin{array}{l}4 \\
2 \\
2\end{array}$ & $\begin{array}{l}9 \\
3 \\
6 \\
2 \\
2\end{array}$ & $\begin{array}{l}4 \\
6 \\
6 \\
1\end{array}$ & $\begin{array}{l}1 \\
3\end{array}$ & & & 1 \\
\hline & $\begin{array}{l}A B \\
B C \\
C A^{\prime} \\
A C\end{array}$ & & 2 & 1 & 1 & & & & \\
\hline & $G . W_{下}$ & & & & 1 & 1 & & & \\
\hline & 話 & 1 & 6 & 19 & 15 & 4 & 0 & 0 & 1 \\
\hline
\end{tabular}

体八の放電は見かけ上直ぐ上の導体の放電を吸仪する 形で現われるので，中，下相に放電のないこの例では G.W下 の効果がないのは当然の結果之いえる。

傾斜地の場合：G.W下 の方る場合，ない場合の結 果を比較して第 4 表に示した。 $G . W$ 下 のある場合の $H / h g=2$ では，しゅへい失敗はなく，G.W下 のない 場合は，上，中相に 1 回ずつ放電した。他のケースの しゃへい失敗の尔布状沉は筑 12 図に示した。G. $W_{\text {下 }}$ のある $H / h g=1$ の下相の分布図に点線で示したのは G.W下への放電を示し，香し，G.W下がなけ机は下 相に放電していたと溚えられ，G.W下 の効果が表わ れている。图中の（）内の数値は面積表表わし， G.W下への放電分の面積は 100 で，送電線への放笔

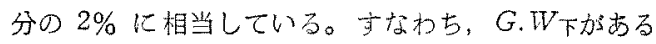
ために，しゃへい率が $2 \%$ だけ良くなる。企体のしゃ

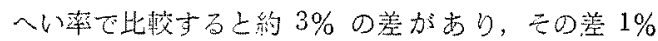

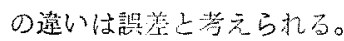

$B$ タイプモデルの結果は，放電分布状沉上上もに第 5 表佂した。ケース1は G.W下のない場合，ヶー

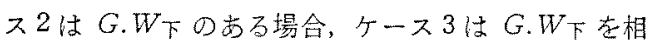
導体直下上り $3 \mathrm{~m}$ 分張出した場合である。第 5 表の集 計では同時放電は各 1 回之报い，内訳は， $A B, B C$ の 上う㐳示した。計橍はしゃへい失敗数から同時放電数 を差引いたものでしゃへい率はこの值で算出した。

各ケースのしゃへい率は 94 97\% であまり差がな い。しかし，ケース 3 で G.W下に2 回放電加あり G.W下を張り出した埤累は一応認めら机る。ケース 2 で $G . W_{\text {下 }}$ に放電が生じないのは，〈3.2〉節(1) O結 果加万考元机ば当然の結果上いえる。

以上のように，G.W下 そ，G.W上のしゃへい失敗 分を吸収することは因喤でちり，㑯斜地といえど屯， G.W上による雷しゃへい重点を置くべきである。

\section{4. 結果に基づいた雷しゃへいの考え方}

$\langle 4 \cdot 1\rangle$ 送電線雷撃領域之大地雷荼領域第 13 図 は各重実験結果加ら，〈3.2〉飾（1）の結果借基づいて 基本特性としゃへい特性加ら $h g=0.5 \mathrm{~m}$ 亿ついて，H 別に送電線への放電の剖合 $P_{L}$ を $A / h g$ との関䋆で示 し，平均的な直線引引たすのである。

いま，送電緗への雷整率を $P_{L}$ とすれば，大地への 雷慗率 $P_{E}$ は $\left(100-P_{L}\right)$ で自動的借決まる。したが っ に対応する $A / h g$ を $H$ ごよに第 13 圆加ら求的てプ

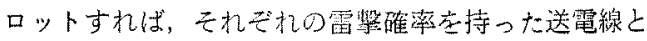
大地への雷整領域に分割卞ることができる。

\section{$\langle 4 \cdot 2\rangle$ 架空地線雷撃領域}




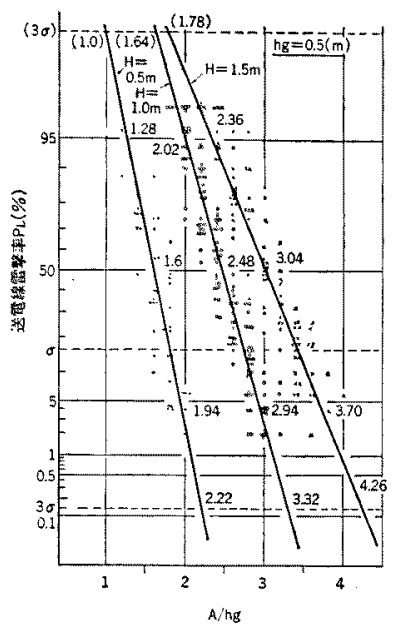

第 13 図 $P_{L}$ 己 $A / h g$ の関倸

Fig. 13. Relation of $P_{L}$ and $A / h g$.

送電線雷熬領域加ら相導体雷整領域を荎引いたもので 示すことができる。第 6 表はしゃへい特性の試験結果 から，送電線，相導体きれぞれへの雷撃籁围を示した すのである。それぞれの䨝摮範囲京示す $A / h g$ の限 は各ケースごよに見れば一致している。相導体雷僌範

第 6 表 各種しゃへい特性から求めた雷撃 籍毌の比較 $(h g=0.5)$

Table. 6. Comparision of lightning range from all kinds shielding charactristics. (hg $=0.5$ )

\begin{tabular}{|c|c|c|c|c|}
\hline$h c / h g$ & $H(\mathrm{~m})$ & 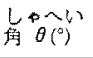 & 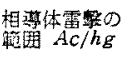 & 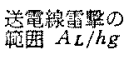 \\
\hline \multirow{5}{*}{0.9} & \multirow{5}{*}{1.0} & $45^{\circ}$ & $0.86 \sim 3.06$ & $1.94 \sim 3.06$ \\
\hline & & $"$ & $0.98 \sim 3.20$ & $2.00 \sim 3.20$ \\
\hline & & $37.5^{\circ}$ & $1.20 \sim 2.96$ & $1.86 \sim 3.02$ \\
\hline & & $30^{\circ}$ & $1.26 \sim 3.00$ & $2.00 \sim 3.06$ \\
\hline & & $15^{\circ}$ & $2.60 \sim 3.00$ & $2.00 \sim 3.24$ \\
\hline \multirow{15}{*}{0.7} & \multirow{4}{*}{1.5} & $45^{\circ}$ & $1.95 \sim 3.87$ & $2.20 \sim 3.87$ \\
\hline & & $"$ & $1.72 \sim 3.76$ & 2. $20 \sim 3.76$ \\
\hline & & $37.5^{\circ}$ & 2. $20 \sim 3.70$ & $2.40 \sim 3.94$ \\
\hline & & $"$ & $2.20 \sim 3.40$ & $2.20 \sim 3.82$ \\
\hline & \multirow{7}{*}{1.0} & $45^{\circ}$ & $1.12 \sim 3.08$ & $1.80 \sim 3.08$ \\
\hline & & " & $1.06 \sim 3.00$ & $1.88 \sim 3.00$ \\
\hline & & " & $1.00 \sim 3.34$ & $2.00 \sim 3.34$ \\
\hline & & $37.5^{\circ}$ & $1.20 \sim 3.20$ & $2.00 \sim 3.20$ \\
\hline & & $"$ & $1.20 \sim 3.00$ & $1.88 \sim 3.20$ \\
\hline & & " & 1. $18 \sim 2.94$ & $1.82 \sim 2.94$ \\
\hline & & $30^{\circ}$ & 1. $74 \sim 3.20$ & $2.00 \sim 3.24$ \\
\hline & \multirow{4}{*}{0.5} & $37.5^{\circ}$ & $0.20 \sim 2.06$ & $1.40 \sim 2.06$ \\
\hline & & $30^{\circ}$ & $0.25 \sim 2.00$ & $1.40 \sim 2.00$ \\
\hline & & $15^{\circ}$ & $0.40 \sim 1.95$ & $1.10 \sim 1.95$ \\
\hline & & $10^{\circ}$ & $0.90 \sim 2.00$ & $1.20 \sim 2.00$ \\
\hline \multirow{3}{*}{0.5} & \multirow{3}{*}{1.0} & $45^{\circ}$ & 1. $14 \sim 3.30$ & $1.80 \sim 3.30$ \\
\hline & & $37.5^{\circ}$ & $1.40 \sim 3.00$ & $2.06 \sim 3.20$ \\
\hline & & $30^{\circ}$ & $1.80 \sim 3.00$ & $2.00 \sim 3.04$ \\
\hline
\end{tabular}

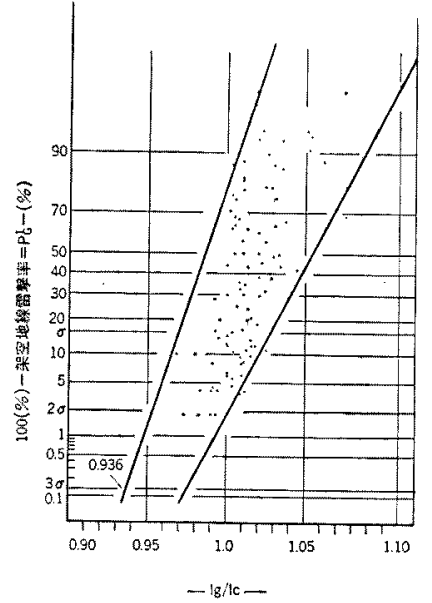

第 14 図 $P_{G}^{\prime}$ と $\lg / l c$ の関係

Fig. 14. Relation of $P_{G}^{\prime}$ and $l_{\theta} / l_{c}$.

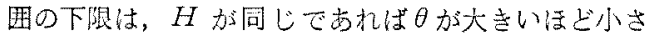
く，相導体雷摮籍国统広くなる。

この傾向は $\theta$ と $H$ 定ししし，hc/hg 大きく しても同しである。と机は架空地線雷整範国（領域） が架架地線と相導体の这置関係で变わることを示して

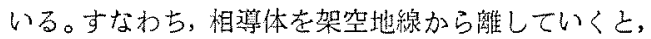
遂には相等体がない場合乞同じになり，架空地線雷鸪 籍围住電線のそれと一致する。逆に相導体を架空地 線に近づけて行けげ，遂には相祡体乙架空地線は重な り，架空地線雷撃籍囲はなくなる。このように贺空地

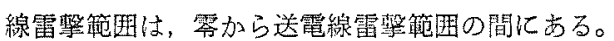

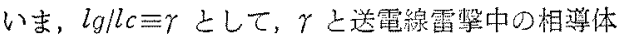
雷整の割合 $P_{G}{ }^{\prime}$ の関係定実験結果加求力る上第 14 四のようになる。完全に全ての雷謷加架空地線に起き る完全架空地線雷揧頜域在決定する $\gamma$ は, 常識的に $\gamma<1$ であることは明らかである。

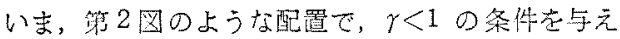
るならば、この条件を渾す点の轨跡は，

$$
\begin{aligned}
(A & \left.+\frac{X \gamma^{2}}{k}\right)^{2}+\left(H-\frac{h g-h c \gamma^{2}}{k}\right)^{2} \\
= & \frac{\gamma^{2}\left(h c^{2}+X^{2}\right)-h g^{2}}{k}+\left(\frac{h g-h c \gamma^{2}}{k}\right)^{2} \\
& +\left(\frac{X \gamma^{2}}{k}\right)^{2} \ldots \ldots \ldots \ldots \ldots \ldots \ldots \ldots \ldots \ldots \ldots \ldots
\end{aligned}
$$

$$
\text { ここに, } k=1-\gamma^{2}
$$

のように円の式となる。架空地線雷盤領域はこの円の 内側で表扣される。

〈4.3〉雷慗領域の分割第 15 図は雷撉領域を 分割した1例である。 $E$ 扰よじ $L$ 曲線は，それぞれ 大地之送電線八の霞整の限界を符 13 図の $3 \sigma$ で描い 


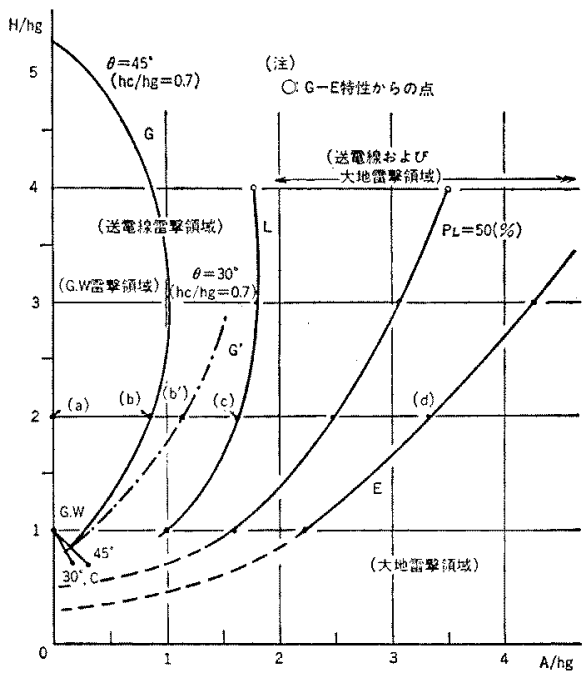

第 15 図 霓整領域の分制

Fig. 15. Division of lighting stroke area.

たむのである。G曲眿は架空地線雷㢣の限界を示す意 味で，同㧼に第 14 困のシビア側の直線の $3 \sigma(0.936)$ を仮定し，hc/hg=0.7, $\theta=45^{\circ}$ について描いた。点線 の $G^{\prime}$ 曲線仕 $\theta=30^{\circ}$ の場合を示す。

いま，H/hg=2 の最終ステップの雷慗を考えると， 送電線雷整筑国は，線分 $\overline{a d}$, 相導体雷整筑围は線分 $\overline{b d}$ ，そして，架空地線雷撃範䦨は線分 $\overline{a b}$ で表わせ る。このように考えた $b\left(b^{\prime}\right)$ 点の $A / h g$ と第 6 泰の 結果の下限它比較方ると多少の差はある妨傾问の矛盾 はない。

〈4.4〉しゃへい条件以上の雷熬湎域の分割図 を用いて，しゃ八い条件在求加方法老示す。

ここではH/hg を仮定して，とれ以下の雷媻はない として考えを谁的。

しゃへい条化は，仮定した H/hgにおいて，架空地

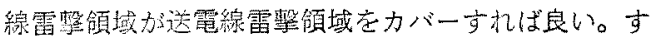
な放古，第 15 四の $G$ 曲線を移動させ，仮定した $H / h g$ で $E$ 曲鼣と交わるようにすれば良い。G曲線 の移動は，相導体の位置の移動定表加すのて $h c / h g=$ 一宿とすれば $\theta$ 老替えればよい。

注意する点は，G曲楾の曲率が $\gamma$ に影䬸されるの

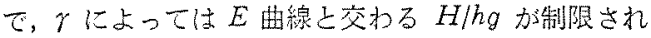
る。第 15 四の例で $H / h g \fallingdotseq 1$ 以上の所に交点老求 めよう上すると, 必ず $H / h g<1$ で 1 度交わるように なる。

$\langle 4.5\rangle$ 今後の問題点 以上, 実験結果に基づい て雷しゃへいの1つの考え方を示したが，害際との対 比という点では問題力゙ある。すなわち，負極性の開䦥
インパルスによる実験を基にしているが，正極性の力 が自然雷に近いしいう説もあり(1)，極性問題はモデル

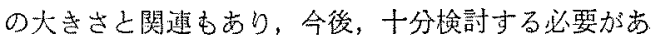
る。また，G曲線を決める $\gamma$ の値屯放霓現象面加ら

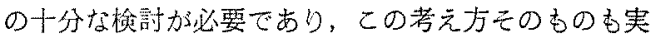
績との対比に扔いて修正，梌討加必要と教える。

\section{5. むすひ}

以上，主要点在列記す㣗ば次のとおりである。

（1）従来，雷しょへいの檢討は相導体 1 条で検討 する例が多く結果に差が生じることが危ぐされていた

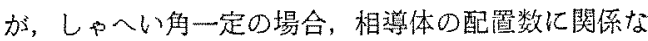
くしゃへい率は一定になり，し中へい失敗の分布学考 えなけ机ば徒来ど扣りの考え方で良いととを示した。

(2) 傾斜地の送電線の谷側回線の実効しゃへい率 加悪化するととは定性的に知られていたが，この点に 検討定加元，傎斜地の実効しゃい角は，しゃへい角 に傾斜角を加えたるので代表できることを示した。

（3）相導体の機压考えた場合しんへい率は 機任と雷慗の亟性㕶に逆のときに悪化し，同じとき は良くなる。その程度は相導体の表面電位傾度 $10 \mathrm{kV} /$ $\mathrm{cm}$ あたり，DCで $3.5 \sim 4 \% ， A C$ が $2 \sim 3 \%$ で， DC の方が若干その效果が大きいととを示した。

(4) 誘導対策上加ら相導体下部罚㯰されるし中 へい線の雷しゃへい効果は，傾斜地で効果力゙現われる が非常に少なく，雷しゃへいの面加らは架空地線のほ うが有妁であるとと宛した。

（5）一連の奏験結果に検討を加えながら，雪しゃ ヘいの1つの考元方を提示した。

終わりに，本研究の奏施にあたり，ご指導とご助言

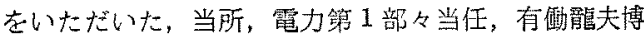
士，菜統絶緣研究室長，大和玄一博士，执よひ前塩原 実駼場厓，中村 宏博士に深く感謝いたします。また 終始実験に協力いただいた䒺統絶縁研㠰室員および， 程原実験場関係者汇深く感謝します。

(昭和 49 年 6 月 26 日受付，同 50 年 3 月 29 日再受付)

\section{文献}

(1) C. F. Wagner, et al: Trans. Amer Inst. Elect. Engrs 60, p. 313 (1941)

(2) C.F. Wagner, et al: Trans. Amer Inst. Elect. Engrs 61. p. $96(1942-2)$

(3) 高松- 河角: 電学誌 90 , p. 673 (昭 45-4)

(4) R. W. Sorensen, et al: Trans. Amer Inst. Elect. Engrs 61 . p. $159(1942-3)$

(5) 三田: 範試研究報告 510 (1950-1)

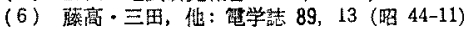

(7) H. R. Armstrong\& E. R. Whitehead: IEEE Trans. Power Apparatus Syst. PAS-86, p. 1223 (1964-12)

(8) H.R. Armstrong \& E.R. Whitehead: IEEE Trans. Power Apparatus Syst. PAS-87, p. 270 (1968-1)

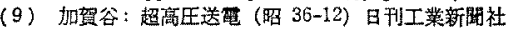

